\title{
Journalism ethics and climate change reporting in a period of intense media uncertainty
}

\author{
Bud Ward* \\ PO Box 1317, White Stone, Virginia 23578, USA
}

\begin{abstract}
The best editors and reporters in the USA adhere to a well-defined, if somewhat abstract, code of journalistic ethics, but doing so during a time of revolutionary changes in the mainstream media - and during a severe financial crisis nationally and globally - presents peculiar challenges. How those challenges may affect the coverage of global climate change presents its own set of questions, and the outcome for journalism ethics is as unpredictable as it is for climate change policies and for journalism itself. This article raises issues that will have to be sorted out over time if the public is to be kept well informed about the challenges, risks, and opportunities posed by climate change.
\end{abstract}

KEY WORDS: Journalism · Climate change $\cdot$ News media $\cdot$ Global warming $\cdot$ Journalism ethics Resale or republication not permitted without written consent of the publisher

\section{INTRODUCTION}

Many veterans of traditional journalism stick to a well-established, if often abstract and unenforceable, code of professional ethics that compares favorably with the strictest such codes applicable to many other fields. Non-journalists might find that reality surprising, given the all too frequent ethical lapses occurring in, and subsequently reported by, the media.

Ethical considerations arise in virtually all aspects of news and opinion writing. It is true that at times, such as now, of intense concern over basic realities, such as employment security and the overall future and direction of the journalistic enterprise in its entirety, ethical considerations can fall far from front-stage. That is true even among the field's most ardent practitioners: it is hard to put your journalistic ethical principles into practice when your first priority is to make sure that your resume is up to date.

In fact, the ongoing and painful metamorphosis in the USA from a paper-oriented daily journalism to one better characterized by bytes and blogs raises real questions, not only about the future of individual reporters' jobs, but about journalism generally and journalism ethics in particular. Will the journalistic traditions and mores that have characterized much of 20th century US news reporting carry over readily into the new media?

\section{JOURNALISM ETHICS CODE}

'Seek truth and report it' the US-based Society of Professional Journalists (SPJ) says in its code of ethics (http://www.spj.org/ethicscode.asp), first adopted in September 1996 but adapted from codes dating back to 1926. 'Journalists should be honest, fair and courageous in gathering, reporting and interpreting information.' Clear enough. But surely it does not go far enough, even when followed up, as it is, by 17 elaborations.

'Act independently' the SPJ code counsels at another point. 'Journalists should be free of obligation to any interest other than the public's right to know' and they should be 'accountable to their readers, listeners, viewers, and each other'. Clarifying their coverage and 
inviting dialogue with the public over journalistic conduct are among the ways they can do that.

One of the common ethical principles in news reporting is that journalists cannot be both observers and participants in an event on which they are reporting. That is, they cannot have had any influence on the planning, implementation, or outcome of an event and be expected to observe and report objectively on that same event.

In other words, 'avoid entangling alliances', to borrow a phrase often attributed (not without debate) to George Washington from his Farewell Address.

\section{JOURNALISM ETHICS IN PRACTICE... ON THE BEAT}

So how precisely does one avoid entangling alliances when it comes to reporting? Before going directly to environmental journalism - and specifically to the coverage of global climate change-let's consider an example from the religious beat.

To avoid any appearance of an entangling alliance, will readers or viewers prefer that the reporting on the Vatican be done by a Catholic, who might have the most first-hand knowledge and maybe even better news sources? Or by a non-Catholic? By an agnostic? Or by an atheist? Or does it matter, so long as the reporting is judged to be fair and independent?

Now take the environmental beat. Surely it is a clear violation of journalistic ethics for a news reporter representing himself or herself as being independent to have, for instance, any membership affiliation with an organization active for or against environmental protection efforts. Does that mean too that they can't have friends and social acquaintances involved with such efforts? Are their spouses' activities similarly open to challenges?

So just how far do the questions and ethical traps go? Should reporters covering issues related to clean air and clean water mock some kind of indifference to them, some kind of mutual preference?

In covering global climate change, issues related to journalism ethics-like other things touching or touched by that omnipotent and all-encompassing issue-become murkier still. It is one thing for a reporter to avoid being a 'participant' in a membership organization, but an entirely different matter for any sentient human being-yes, journalists are sentient human beings - to avoid participation in matters of clean air, clean water, or the climate! The simple fact is that journalists, like all of us, have a direct personal interest in a healthy environment and climate critical to sustaining their society's and their own health and economic well-being.

\section{THE CLIMATE CHANGE-JOURNALISM ETHICS EQUATION}

Consider another aspect of journalistic ethics as it applies to covering climate change. One element of the SPJ Code of Ethics urges reporters to 'give voice to the voiceless; official and unofficial sources of information can be equally valid'. Another cautions reporters to 'support the open exchange of views, even views they find repugnant' (note that it is 'repugnant' and not 'factually inaccurate' here).

In reporting on climate change and the findings in the physical and earth sciences defining it, US reporters for many years practiced what critics contend is a 'false balance', providing space disproportionate to its scientific credibility to perspectives running counter to what is now widely accepted as the 'established' scientific judgment. In effect, reporters may for too long have been balancing opinions about science when in fact they might better have been evaluating and reporting evidence based on the science. Accuracy can trump balance in such a case, so that one perspective gets $90 \%$ of the column inches, based on the standard of evidence, and another perhaps 5 or $10 \%$, or maybe none at all.

Just as that approach to covering climate science based on evidence and not sheer opinion has changed throughout much of the western world, it appears in recent years to have also changed, albeit much later, among many US news reporters.

So, instead of the over-simplified notion of providing 'balance' in reporting on news involving differing perspectives, journalists increasingly, and rightly, take their clues from the leading and acknowledged scientific experts when it comes to the facts and causes of global climate change. That means, in effect, reporting as a given - until science shows otherwise-that warming of Earth actually is occurring and that human activities have a significant role, though not the only one, in that warming.

Issues of journalism ethics in dealing with climate change go much farther than that. Assume, for the purposes of discussion, that the effects and impacts of global warming just may be as dire as a number of leading scientists suggest, threatening not only vast ecological systems and the natural resources dependent on them, but also posing great risks of accelerated extinctions, forced human migrations from low-lying lands, diminished food resources for a growing population, and so forth. What then are the ethical responsibilities facing news reporters? Is it up to them to sustain the clarion call by way of front-page headlines and repeated broadcast 'breaking news' alerts, despite what some observers now dismiss as 'climate fatigue' on the parts of their already-harried audiences? Isn't 
that too much like making and not merely reporting the news that others-acclaimed scientists or leading policy makers - have as part of their portfolios?

So what if the nature of the threatened worst-case climate change outcomes are to be most clearly manifested only for future generations, or only as they directly affect audiences geographically far removed from one's own readers or viewers? Do the journalists' ethical responsibilities differ if it is just 'some other population' (or perhaps even some other species) that is at greatest risk, and not the one closest to them in time and space?

Journalists have profound ethical responsibilities covering issues as expansive and critical (not many are, perhaps) as climate change. That they are dealing with these issues during a time of profound change in their own field, and during a time of profound global economic and financial uncertainty, compounded by ongoing threats of divisive wars and terrorist activities, only confounds their approach to these issues.

\section{THE UNCERTAIN OUTLOOK FOR JOURNALISM}

Ethical issues such as those raised here present practical day to day challenges about which the best journalists give the most thorough deliberation. While

Editorial responsibility: Stephanie Suhr-Sliester, Oldendorf/Luhe, Germany there is no professional dis-barring or black-balling protocol in the USA for reporters running afoul of established ethical principles, offenders can often face something equally damning - the loss of standing among their own professional peers and the attendant loss of credibility with their audiences, and therefore the reporter's only real reason for being.

How these ethical principles will in fact play out over the coming years and decades in light of the pressures the mainstream news media (MSM) are currently facing remains uncertain. But what remains a veritable certainty is that, without the acknowledged credibility a journalist needs to have a measurable impact on an issue as important as global climate change, an interested citizenry inevitably will have to turn elsewhere for its information.

Just where that might be is anyone's guess. Some mix of the World Wide Web, various blogs, news aggregators like Google, Yahoo and others, including some remnants of traditional news organizations, are among the leading candidates.

Given the profound changes sweeping across the media landscape, it may be months or years before the public decides which media format best meets its needs for staying abreast of the sweeping implications of climate change, and climate change mitigation and adaptation strategies.

Submitted: December 10, 2008; Accepted: December 10, 2008 Proofs received from author(s): January 7, 2009 